\title{
Chemical characterization, antioxidant and inhibitory effects of some marine sponges against carbohydrate metabolizing enzymes
}

\author{
Mohamed Shaaban ${ }^{1,2^{*}}$, Howaida I Abd-Alla ${ }^{1}$, Amal Z Hassan ${ }^{1}$, Hanan F Aly ${ }^{3}$ and Mohamed A Ghani ${ }^{4}$
}

\begin{abstract}
Background: More than 15,000 marine products have been described up to now; Sponges are champion producers, concerning the diversity of products that have been found. Most bioactive compounds from sponges were classified into anti-inflammatory, antitumor, immuno- or neurosurpressive, antiviral, antimalarial, antibiotic, or antifouling. Evaluation of in vitro inhibitory effects of different extracts from four marine sponges versus some antioxidants indices and carbohydrate hydrolyzing enzymes concerned with diabetes mellitus was studied. The chemical characterizations for the extracts of the predominating sponges; SP1 and SP3 were discussed.
\end{abstract}

Methods: All chemicals served in the biological study were of analytical grade and purchased from Sigma, Merck and Aldrich. All kits were the products of Biosystems (Spain), Sigma Chemical Company (USA), Biodiagnostic (Egypt). Carbohydrate metabolizing enzymes; a-amylase, a-glucosidase, and $\beta$-galactosidase (EC3.2.1.1, EC3.2.1.20, and EC3.2.1.23, respectively) were obtained from Sigma Chemical Company (USA).

Results: Four marine sponges; Smenospongia (SP1), Callyspongia (SP2), Niphates (SP3), and Stylissa (SP4), were collected from the Red Sea at Egyptian coasts, and taxonomically characterized. The sponges' extracts exhibited diverse inhibitory effects on oxidative stress indices and carbohydrate hydrolyzing enzymes in linear relationships to some extent with concentration of inhibitors (dose dependant). The extracts of sponges (3, 1, and 2) showed, respectively, potent-reducing power. Purification and Chemical characterization of sponge 1 using NMR and mass spectroscopy, recognized the existence of di-isobutyl phthalate (1), di-n-butyl phthalate (2), linoleic acid (3), $\beta$ sitosterol (4), and cholesterol (5). Sponge 3 produced bis-[2-ethyl]-hexyl-phthylester (6) and triglyceride fatty acid ester (7).

Conclusion: Marine sponges are promising sources for delivering of bioactive compounds. Four marine sponges, collected from Red Sea at Egyptian coasts, were identified as Smenospongia (SP1), Callyspongia (SP2), Niphates (SP3), and Stylissa (SP4). The results demonstrated that different sponges extracts exhibited inhibitory effects on oxidative stress indices and carbohydrate hydrolyzing enzymes in linear relationships to some extent with concentration of inhibitors (dose dependant). The extracts of sponges $(3,1$, and 2) showed, respectively, potentreducing power. Chemical characterizations of sponges SP1 and SP3 were discussed. Based on this study, marine sponges are considered as talented sources for production of diverse and multiple biologically active compounds.

Keywords: Sponges, Chemical characterization, $a$-amylase, a-glucosidase, $\beta$-galactosidase, Antioxidants

\footnotetext{
*Correspondence: mshaaba_99@yahoo.com

${ }^{1}$ Chemistry of Natural Compounds Department, Division of Pharmaceutical

Industries, National Research Centre, Dokki, Giza 12622, Egypt

${ }^{2}$ Institute of Organic and Biomolecular Chemistry, University of Göttingen,

Tammannstraße 2, Göttingen D-37077, Germany

Full list of author information is available at the end of the article
} 


\section{Background}

Pharmaceutical interest in sponges was aroused in the early 1950 s by the discovery of a number of unknown nucleosides: spongothymidine and spongouridine in the marine sponge Cryptotethia crypta [1,2]. These nucleosides were the basis for the synthesis of Ara-C, the first marine-derived anticancer agent and the antiviral drug Ara-A [3]. Ara-C is currently used in the routine treatment of patients with leukaemia and lymphoma. More than 15,000 marine products have been described up to now $[4,5]$; Sponges are champion producers, concerning the diversity of products that have been found [6]. They are responsible for more than 5,300 different products and every year hundreds of new compounds are being discovered [4]. Most bioactive compounds from sponges can be classified as anti-inflammatory, antitumor, immuno- or neurosurpressive, antiviral, antimalarial, antibiotic, or antifouling [5-9].

Exogenous chemical and endogenous metabolic processes in the human body or in the digestive system might produce highly reactive free radicals, especially oxygen-derived radicals, which are capable of oxidizing biomolecules, resulting in cell death and tissue damage. Almost all organisms are well protected against free radical damage by anti-oxidative enzymes such as superoxide dismutase and catalase (CAT), or by chemicals such as carotenoids, polyphenols, and glutathione [10]. However, when the process of antioxidant protection becomes unbalanced, deterioration of physiological functions may occur resulting in diseases and accelerated aging. There is an increasing evidence, indicating that reactive oxygen species and free radical-mediated reactions are involved in degenerative or pathological events such as aging, cancer, coronary heart ailments, and Alzheimer's diseases [11]. Moreover, the suppression of the oxidative stress and inflammatory were responded through the inhibition of tumor necrosis factor $\beta$-(TNF- $\beta$ ) signaling [12]. Natural triterpenes isolated from different marine sponges inhibited iNOS expression and the activation of NF- $\beta$, while polyketides showed antitumoural activity [13]. Most screenings of secondary metabolites of biomedical importance from marine sponge extracts reported an inhibitory effects that turned out to be have strongly cytotoxic effects $[14,15]$.

In this article, evaluation of in vitro inhibitory effects of different extracts from four marine sponges Smenospongia (SP1), Callyspongia (SP2), Niphates (SP3), and Stylissa (SP4) versus some antioxidants indices and carbohydrate hydrolyzing enzymes concerned with diabetes mellitus. The studied sponges were collected from Red Sea, Hurghada, at Egyptian coasts. Alternatively, the chemical characterizations for two extracts of the predominating sponges; SP1 and SP3 were discussed on the bases of different chromatographic and spectroscopic means. In accordance, di-isobutyl phthalate (1), di-nbutyl phthalate (2), linoleic acid (3), $\beta$-sitosterol (4), and cholesterol (5) were obtained from SP1; while SP3 delivered bis-[2-ethyl]-hexyl-phthylester (6) and triglyceride fatty acid ester (7).

\section{Methods}

Four marine sponges belonging to the genus Smenospongia (SP1), Callyspongia (SP2), Niphates (SP3) and Stylissa (SP4) were collected from Hurghada at El-Gouna and Shaa'b south Giffton island at depth of 5-8 m. Morphologically, the sponges were characterized and specimens of them were deposited at Red Sea Marine parks, P.O. Box 363-Hurgada, Red Sea, Egypt.

The four sponges were individually extracted by DCM-MeOH (2:1), followed by filtration, and the afforded DCM layers were extracted and evaporated in vacuo to dryness. Extracts of sponges were applied to a series of chromatographic purifications including Flash chromatography on silica gel (230-400 mesh), Size exclusion chromatography was done on Sephadex LH-20, and PTLC to isolate their produced bioactive compounds in pure forms. Purity of the yielded compounds were monitored by $R_{\mathrm{f}}$ values were measured on Polygram SIL $\mathrm{G} / \mathrm{UV}_{254}$ TLC cards. This lead to isolate the following compounds; Linoleic acid; (9Z,12Z)-9, 12-octadecanoic acid (3), $\beta$-sitosterol (4), Cholesterol (5), Di-(2-ethylhexyl)phthalate(DEHP)(6), and Triglyceride fatty acids mixture (7) were assigned with the aid of different spectroscopic means as follows; NMR $\left({ }^{1} \mathrm{H} \&{ }^{13} \mathrm{C}\right.$ NMR) was served using Varian Unity $300(300.145 \mathrm{MHz}$; and Varian Inova $600(150.820 \mathrm{MHz})$ spectrometers. ESI MS (Thermo Finnigan LCQ with quaternary pump Rheos 4000 (Flux Instrument); Thermo Scientific, USA). EI MS (a Finnigan MAT 95 spectrometer $(70 \mathrm{eV})$; Thermo Scientific, USA. GC-MS was measured on a Trace GC-MS Thermo Finnigan chromatograph, ionization mode EI (70 eV).

The in vitro antioxidant study of the sponges extracts were carried out using Carbohydrate metabolizing enzymes; $\alpha$-amylase, $\alpha$-glucosidase, and $\beta$-galactosidase. The antioxidant scavenging activity was studied using serial concentrations of different sponge extracts (10:1000 $\mu \mathrm{g} / \mathrm{mL})$ versus DPPH-free radical. The NO-free radical scavenging activity of extracts was determined according to the method of Sreejayan and Rao [16].

\section{Results and discussion}

\section{Chemical characterization}

Extracts of the four marine sponges Smenospongia (SP1), Callyspongia (SP2), Niphates (SP3), and Stylissa (SP4) were applied to a series of chromatographic applications, and hence to identify their bioactive constituents 
Table 1 DPPH inhibition percent of the four sponges extracts

\begin{tabular}{lllll}
\hline Concentrations & \multicolumn{4}{c}{ Extracts of the four sponges } \\
\cline { 2 - 5 } & SP1 & SP2 & SP3 & \\
\hline $10 \mu \mathrm{g} / \mathrm{mL}$ & $10.85 \pm 5.42^{\mathrm{c}}$ & $47.7 \pm 0.84^{\mathrm{e}}$ & $26.31 \pm 0.50^{\mathrm{d}}$ & $16.39 \pm 4.63^{\mathrm{d}}$ \\
$50 \mu \mathrm{g} / \mathrm{mL}$ & $10.77 \pm 2.09^{\mathrm{c}}$ & $60.53 \pm 0.50^{\mathrm{d}}$ & $26.00 \pm 1.38^{\mathrm{d}}$ & $22.38 \pm 1.23^{\mathrm{c}}$ \\
$100 \mu \mathrm{g} / \mathrm{mL}$ & $18.09 \pm 1.1^{\mathrm{b}}$ & $66.45 \pm 0.29^{\mathrm{c}}$ & $34.04 \pm 0.94^{\mathrm{c}}$ & $32.54 \pm 2.14^{\mathrm{b}}$ \\
$500 \mu \mathrm{g} / \mathrm{mL}$ & $22.81 \pm 1.81^{\mathrm{b}}$ & $69.52 \pm 0.97^{\mathrm{b}}$ & $37.39 \pm 1.10^{\mathrm{b}}$ & $35.94 \pm 1.42^{\mathrm{ab}}$ \\
$1000 \mu \mathrm{g} / \mathrm{mL}$ & $30.64 \pm 0.60^{\mathrm{a}}$ & $72.19 \pm 0.69^{\mathrm{a}}$ & $40.17 \pm 0.9^{\mathrm{a}}$ & $38.48 \pm 0.70^{\mathrm{a}}$ \\
LSD 5\% & 5.06 & 1.26 & 1.83 & \\
\hline
\end{tabular}

DPPH is expressed \%; Data are mean \pm SD of 3 replicates; Statistical analysis is carried out using one way analysis of variance (ANOVA) using CoStat: computer program; unshared superscript letters between treatments are significance values at $P<0.001$.

chemically using diverse spectroscopic means. Both sponges, SP1 and SP3, were intensively studied. Five compounds were revealed from SP1; di-isobutyl phthalate (1), di- $n$-butyl phthalate (2), linoleic acid (3), $\beta$-sitosterol (4), and cholesterol (5). The first two esters, diisobutyl phthalate (1, RT: 13.79, 100\%) and di-n-butyl phthalate (2, RT: 14.84, 12\%), were established by GCMS analysis together with further unknown components of RT 19.03 (17\%) and 20.01 (78\%). Purification of sponge 3 (SP3) afforded bis-[2-ethyl]-hexyl-phthylester (6) and triglyceride fatty acid ester (7). In contrast, working up and purification of the extracts obtained from the remaining two sponges SP2 and SP4 delivered multimetabolites, however, with insufficient amounts for analysis.

Based on their chromatographic properties, spectroscopic means (NMR and MS), and comparison with authentic samples and literatures, the obtained structures were deduced as (9Z,12Z)-9,12-octadecanoic acid (3) [17], $\beta$-sitosterol (4) [18,19], cholesterol (5) [20-24], phthalic acid bis-[2-ethyl-hexyl] ester (6) [25] and triglyceride fatty acid mixture (7) [26].

\section{Biological study}

The present results demonstrate the inhibitory effect of different extracts of marine sponges, on antioxidant indices and carbohydrate hydrolyzing enzymes in vitro. The 2,2-diphenyl-1-picrylhydrazyl (DPPH)-free radical scavenging effects of different extracts from marine sponge were shown in Table 1 and Figure 1. All the tested extracts showed appreciable free radical scavenging activities. Extract of SP2 has the strongest radical scavenging activity at different concentrations compared to other extracts followed by SP3 and SP4. However, SP1 showed the lowest radical scavenging activity. A dose-response relationship was found in the DPPH radical scavenging activity, at where the activity increased as the increase of extracts concentrations. SP2 extract was able to reduce the stable radical DPPH to the yellow color to give significant inhibitory percent $47.7 \pm 0.84,60.53 \pm 0.50$,

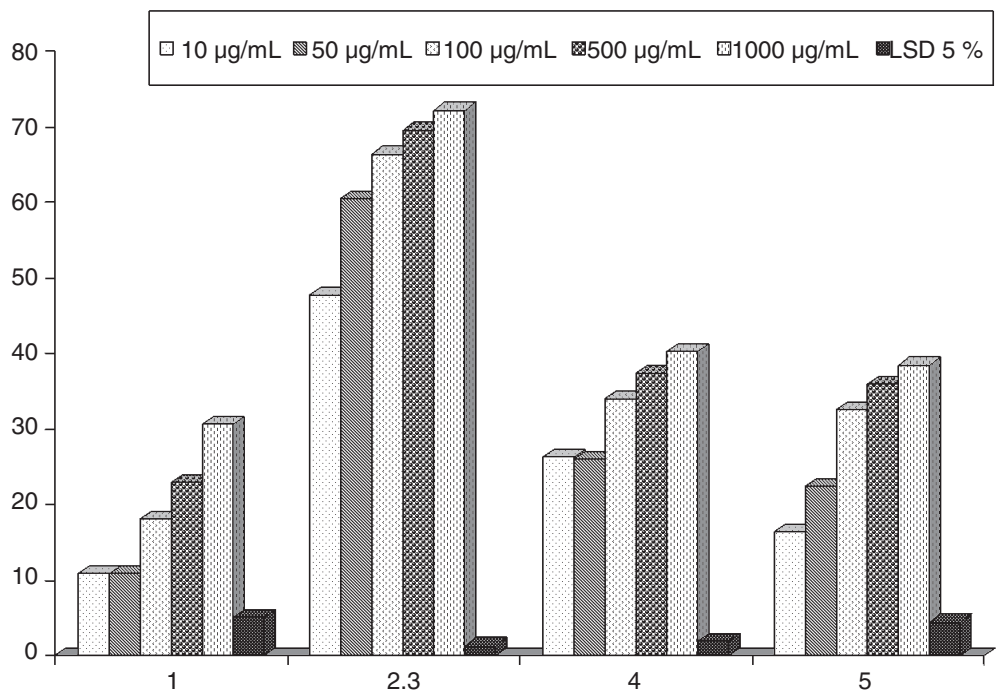

Figure 1 DPPH inhibition percent of the four sponges extracts. 
Table 2 Inhibition percent of nitric oxide (NO) of the four sponges extracts

\begin{tabular}{lllll}
\hline Concentrations & \multicolumn{3}{c}{ Extracts of the four sponges } \\
\cline { 2 - 5 } & SP1 & SP2 & SP3 & SP4 \\
\hline $10 \mathrm{~g} / \mathrm{mL}$ & $10.30 \pm 4.29^{\mathrm{c}}$ & $37.60 \pm 1.68^{\mathrm{e}}$ & $15.26 \pm 6.94^{\mathrm{d}}$ & $13.50 \pm 5.53^{\mathrm{d}}$ \\
$50 \mu \mathrm{g} / \mathrm{mL}$ & $16.92 \pm 3.25^{\mathrm{c}}$ & $39.16 \pm 9.31^{\mathrm{d}}$ & $24.94 \pm 2.89^{\mathrm{c}}$ & $21.41 \pm 4.42^{\mathrm{c}}$ \\
$100 \mathrm{\mu g} / \mathrm{mL}$ & $21.95 \pm 2.86^{\mathrm{b}}$ & $52.13 \pm 6.06^{\mathrm{c}}$ & $33.30 \pm 2.65^{\mathrm{bc}}$ & $27.80 \pm 4.32^{\mathrm{bc}}$ \\
$500 \mu \mathrm{g} / \mathrm{mL}$ & $23.59 \pm 1.01^{\mathrm{b}}$ & $56.58 \pm 3.46^{\mathrm{b}}$ & $36.29 \pm 5.18^{\mathrm{ab}}$ & $30.32 \pm 2.74^{\mathrm{b}}$ \\
$1000 \mu \mathrm{g} / \mathrm{mL}$ & $36.14 \pm 2.93^{\mathrm{a}}$ & $53.85 \pm 5.12^{\mathrm{a}}$ & $44.64 \pm 4.29^{\mathrm{a}}$ & $41.24 \pm 3.27^{\mathrm{a}}$ \\
LSD 5\% & 5.06 & 1.28 & 8.49 & 7.59 \\
\hline
\end{tabular}

NO is expressed as\%; data are mean \pm SD of 3 replicates; statistical analysis is carried out using one way analysis of variance (ANOVA) using CoStat: computer program; unshared superscript letters between treatments are significance values at $P<0.001$.

$66.45 \pm 0.29,69.52 \pm 52$, and $72.19 \pm 0.69 \%$ at concentrations of $10,50,100,500$, and $1000 \mu \mathrm{g} / \mathrm{mL}$, respectively. Alternatively, SP3 showed a reducing inhibitory percent of $\mathrm{DPPH}$ amounted $26.31 \pm 0.50,26.00 \pm 1.38,34.04 \pm$ $0.94,37.39 \pm 1.10$, and $40.17 \pm 0.9 \%$ at the same concentrations of extracts, respectively. Moreover, SP4 showed a significant reducing activity of $16.39 \pm 4.63,22.38 \pm 1.23$, $32.54 \pm 1.42,35.94 \pm 1.42$, and $38.48 \pm 0.70 \%$, respectively. Contrarily, SP1 exhibited the lowest reducing activity compared with aforementioned sponges extracts. The demonstrated inhibitory activity of the DPPH by the sponges extracts might be mainly attributed to their containing of some terpenoidal analogs [26].

Nitric oxide synthase (NOS) is catalyzing the production of nitric oxide (NO). Inducible NOS (iNOS) is expressed by vascular endothelial cells and smooth muscle cells in response to cytokines, unlike the two other types of NOS, which are constitutive. NO produced by iNOS is implicated in inflammatory diseases [27]. NO-free radicals scavenging capacity of the different marine sponges extracts were illustrated in Table 2 and Figure 2. The most reducing capacity was as well considered for SP2, which showed significant ability to reduce the activity of $\mathrm{NO}$ by $37.60 \pm 1.68,39.16 \pm$ $9.13,52.13 \pm 6.06,56.58 \pm 3.46$, and $53.85 \pm 5.12 \%$ at concentrations of $10-1000 \mu \mathrm{g} / \mathrm{mL}$. Alternatively, extract of SP3 exhibited lower significant reducing activity of NO $(15.26 \pm 6.94,24.94 \pm 2.89,33.30 \pm 2.65,36.29 \pm 5.18$, and $44.64 \pm 4.29 \%$ ) with lower extent than those of SP2. Based on the percentage scavenging values, it was remarked that SP1 and SP4 exhibited moderate scavenging effects with linear relationships in a dosedependent manner. Consequently, extracts of SP1 and SP4 recorded potent reducing capability of $41.24 \pm 3.27$ and $38.17 \pm 3.01 \%$, respectively, at a concentration of $1000 \mu \mathrm{g} / \mathrm{mL}$. Tasi et al. [28] reported that food and phytochemicals exerts NO-suppressing activity via three different pathways: the blocking of iNOS expression, inactivation of iNOS catalytic function, and the scavenging NO. While NO suppressing effect was primarily

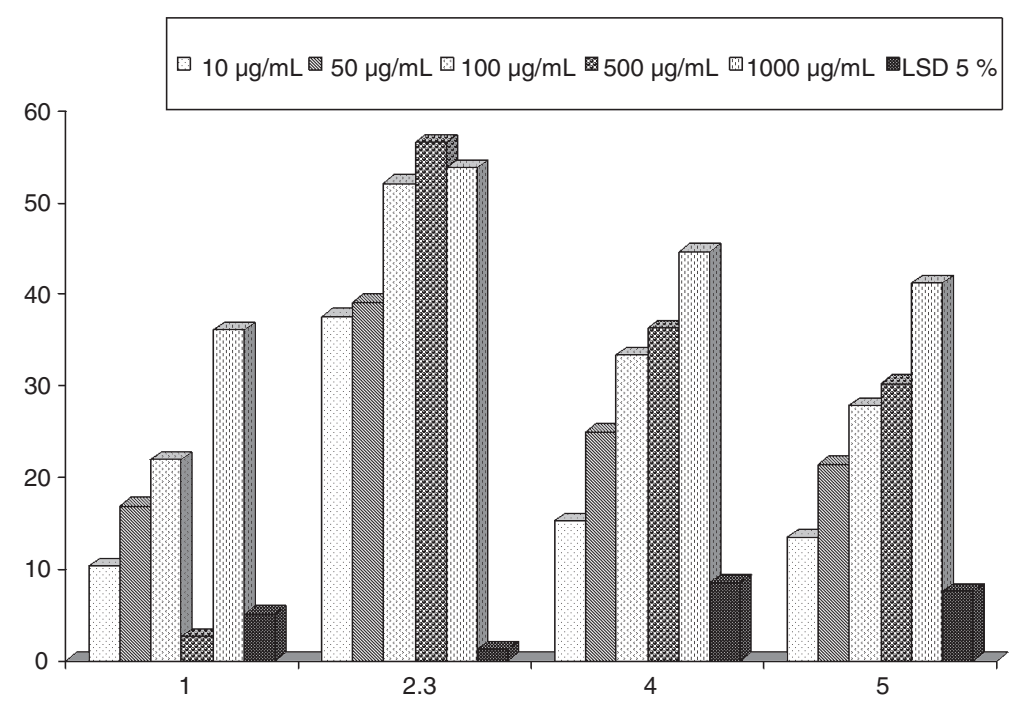

Figure 2 Inhibition percent of NO of the four sponges extracts. 
Table 3 a-Amylase inhibition percent of four sponges extracts

\begin{tabular}{lllll}
\hline Concentrations & \multicolumn{4}{c}{ Extracts of the four sponges } \\
\cline { 2 - 5 } & SP1 & SP2 & SP3 & $18.26 \pm 3.97^{\mathrm{d}}$ \\
\hline $10 \mu \mathrm{g} / \mathrm{mL}$ & $7.41 \pm 2.61^{\mathrm{e}}$ & $92.00 \pm 1.21$ & $24.55 \pm 4.03^{\mathrm{c}}$ & $15.44 \pm 2.68^{\mathrm{e}}$ \\
$50 \mu \mathrm{g} / \mathrm{mL}$ & $18.75 \pm 2.04^{\mathrm{d}}$ & $94.35 \pm 2.69$ & $32.56 \pm 2.07^{\mathrm{b}}$ & $21.72 \pm 3.20^{\mathrm{d}}$ \\
$100 \mu \mathrm{g} / \mathrm{mL}$ & $24.27 \pm 3.07^{\mathrm{c}}$ & $85.22 \pm 4.92$ & $37.14 \pm 0.89^{\mathrm{ab}}$ & $27.38 \pm 1.73^{\mathrm{c}}$ \\
$500 \mu \mathrm{g} / \mathrm{mL}$ & $29.05 \pm 1.47^{\mathrm{b}}$ & $89.38 \pm 8.22$ & $37.97 \pm 1.86^{\mathrm{a}}$ & $33.75 \pm 2.31^{\mathrm{b}}$ \\
$1000 \mu \mathrm{g} / \mathrm{mL}$ & $38.13 \pm 0.64^{\mathrm{a}}$ & $88.40 \pm 7.29$ & 5.18 & $44.59 \pm 1.55^{\mathrm{a}}$ \\
LSD 5\% & 3.9 & NS & 4.32 \\
\hline
\end{tabular}

a-amylase is expressed as \%; data are mean \pm SD of 3 replicates; statistical analysis is carried out using one way analysis of variance (ANOVA) using CoStat: computer program; unshared superscript letters between treatments are significance values at $P<0.001$.

through regulation of cellular iNOS expression. The extracts' effects on the suppressing activity of NO production might be attributed to their containing of polyphenolic compounds or the triterpenes [29].

In alternative manner, extracts of the four sponges were tested against $\alpha$-amylase carbohydrate hydrolyzing enzyme activity (Table 3, Figure 3 ). The four sponges showed potent $\alpha$-amylase inhibitory activity, which may be potentially useful in control of obesity and diabetes. The inhibition of $\alpha$-amylase by SP3 and SP4 was remarked to be as dose dependent, exhibiting the highest significant reducing activity $44.59 \pm 1.55$ and 43.64 $\pm 1.79 \%$, respectively, at a concentration of $1000 \mu \mathrm{g} / \mathrm{mL}$. Furthermore, extract of SP2 exhibited the most dramatic inhibiting effect at 10 and $50 \mu \mathrm{g} / \mathrm{mL}$, displaying insignificant reducing activity $92.00 \pm 1.21$ and $94.35 \pm 2.69 \%$, respectively. In addition, the inhibitory activity of SP2 recorded $88.40 \pm 7.29 \%$ at $1000 \mu \mathrm{g} / \mathrm{mL}$. Consequently, SP3 recorded a significant inhibitory percent of 18.26 $\pm 3.97,24.55 \pm 4.03,32.56 \pm 2.07,37.14 \pm 0.89$, and 37.97 $\pm 1.86 \%$ in a dose-dependent manner at $10,50,500$, and $1000 \mu \mathrm{g} / \mathrm{mL}$, respectively. The anti-amylase inhibitory activity may be due to the ability of phenolic compounds to interact with and/or inhibit proteins enzymes [30].

One therapeutic approach for treating diabetes is to decrease the post-prandial hyperglycemia. This is done by retarding the absorption of glucose through the inhibition of the carbohydrate hydrolyzing enzymes $\alpha$ amylase, $\alpha$-glucosidase, and $\beta$-galactosidase in the digestive tract. Inhibition of these enzymes delay carbohydrate digestion and prolong overall carbohydrate digestion time, causing a reduction in the rate of glucose absorption and consequently blunting the post-prandial plasma glucose rise [31]. Many natural resources have been

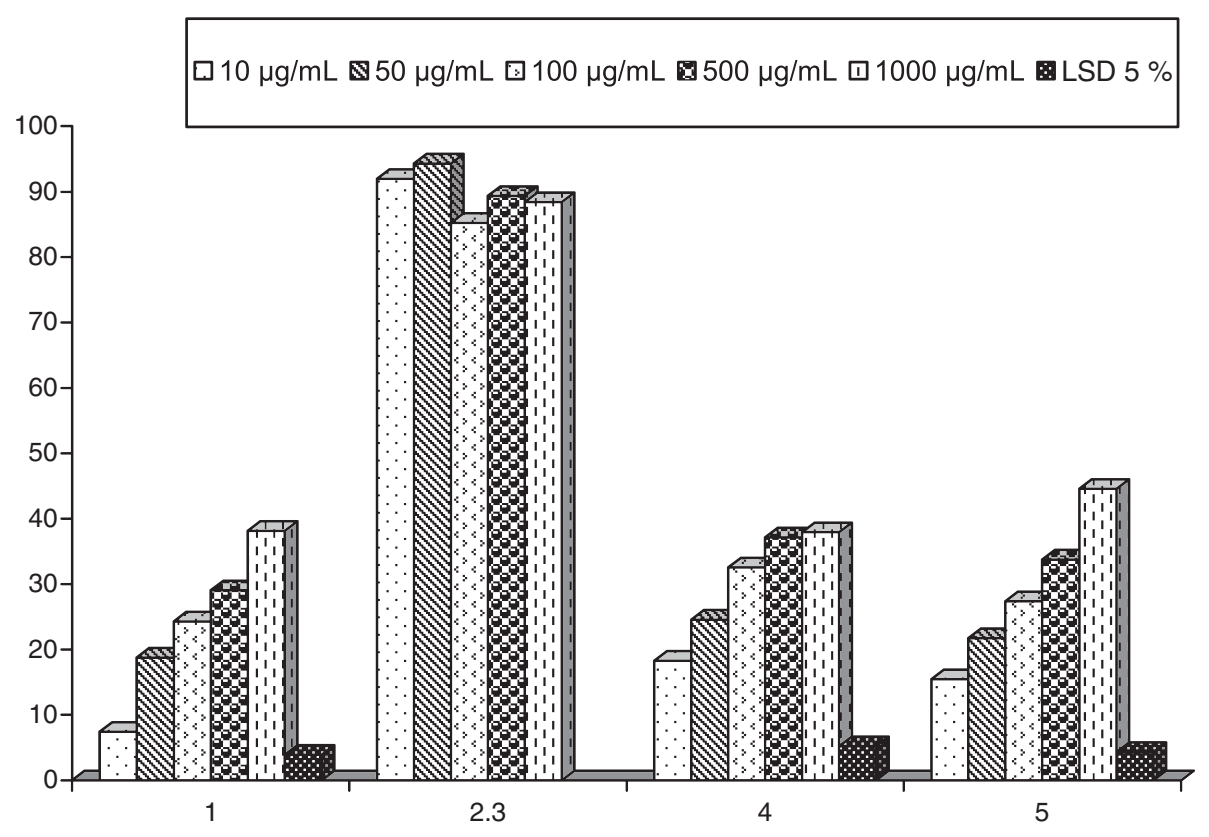

Figure 3 a-Amylase inhibition percent of four sponges extracts. 
Table $4 a$-Glucosidase inhibition percent of the four sponges extracts

\begin{tabular}{lllll}
\hline Concentrations & \multicolumn{3}{c}{ Extracts of the four sponges } \\
\cline { 2 - 5 } & SP1 & SP2 & SP3 & SP4 \\
\hline $10 \mu \mathrm{g} / \mathrm{mL}$ & $8.06 \pm 3.51^{\mathrm{c}}$ & $28.05 \pm 1.63^{\mathrm{c}}$ & $25.45 \pm 4.04^{\mathrm{c}}$ & $23.47 \pm 4.56^{\mathrm{c}}$ \\
$50 \mu \mathrm{g} / \mathrm{mL}$ & $21.08 \pm 4.68^{\mathrm{b}}$ & $37.80 \pm 2.55^{\mathrm{b}}$ & $33.91 \pm 3.15^{\mathrm{b}}$ & $33.49 \pm 1.76^{\mathrm{b}}$ \\
$100 \mu \mathrm{g} / \mathrm{mL}$ & $28.95 \pm 1.44^{\mathrm{a}}$ & $44.21 \pm 2.87^{\mathrm{a}}$ & $40.44 \pm 4.34^{\mathrm{a}}$ & $40.55 \pm 3.08^{\mathrm{a}}$ \\
$500 \mu \mathrm{g} / \mathrm{mL}$ & $27.24 \pm 3.45^{\mathrm{a}}$ & $41.19 \pm 1.59^{\mathrm{ab}}$ & $37.42 \pm 1.14^{\mathrm{ab}}$ & $36.01 \pm 1.78^{\mathrm{ab}}$ \\
$1000 \mu \mathrm{g} / \mathrm{mL}$ & $27.65 \pm 2.37^{\mathrm{a}}$ & $42.5 \pm 2.24^{\mathrm{a}}$ & $39.32 \pm 2.60^{\mathrm{ab}}$ & $38.11 \pm 2.70^{\mathrm{ab}}$ \\
LSD 5\% & 5.97 & 4.14 & 5.93 & 5.93 \\
\hline B-g & & & & \\
\hline
\end{tabular}

$\beta$-galactosidase is expressed as \%; data are mean \pm SD of 3 replicates; statistical analysis is carried out using one way analysis of variance (ANOVA) using CoStat computer program; unshared superscript letters between treatments are significance values at $P<0.001$.

investigated with respect to the antidiabetic and suppression of glucose. The inhibitory effects of the four sponges extracts against $\alpha$-glucosidase carbohydrate hydrolyzing enzyme activity were further studied as listed in Table 4 and Figure 4. Remarkable greater inhibitory effects of SP2 $(40.44 \pm 4.34,39.32 \pm 2.60 \%)$ and SP3 $(40.55 \pm 3.08, \quad 38.11 \pm 2.70 \%)$ than SP1 $(32.22 \pm 3.96$, $29.42 \pm 0.62 \%)$ and SP4 (28.95 $\pm 1.44,27.65 \pm 2.37 \%)$ were deduced at concentrations of 100 and $1000 \mu \mathrm{g} / \mathrm{mL}$, respectively. Hence, the inhibition percent was significantly correlated with the increase in concentration of inhibitors. The fact that $\alpha$-glucosidase and $\alpha$-amylase showed different inhibition kinetics seemed to be due to structural differences related to the origin of the enzymes [32]. Manosroi et al. [33] attributed the anti-diabetic, antiinflammatory, anti-tumor, and anti-proliferative effect of many species, to their constituents of mono, sesquiterpenes, phenolic compounds, and flavonoids such as cinnamic acid, caffeic acid, and rosmarinic acid.

$\beta$-Galactosidase inhibitory activity was finally studied versus the sponges extracts as summarized in Table 5 and Figure 5. Accordingly, SP2 and SP3 provided additional support for the previous finding by having the strongest reducing activity at various concentrations. Hence, SP2 at 500 and $1000 \mu \mathrm{g} / \mathrm{mL}$ displayed significantly the highest inhibitory percent amounted 67.82 \pm 3.94 and $66.86 \pm 3.79 \%$, respectively, followed by SP3 $(62.63 \pm 1.89$ and $62.12 \pm 4.37 \%$, respectively) and SP4 $(54.13 \pm 2.44$ and $55.08 \pm 5.11 \%$, respectively). In contrast, SP1 displayed a comparable insignificant inhibitory activity of $45.89 \pm 4.91,43.77 \pm 4.5 \%$ at 500 and $1000 \mu \mathrm{g} /$ $\mathrm{mL}$, respectively. From the manipulated results, it was deduced significant increase in reducing activity with the increase in concentrations of the individual extract (linear relationship).

\section{Experimental}

The NMR spectra were measured on Varian Unity 300 $(300.145 \mathrm{MHz})$ and Varian Inova $600(150.820 \mathrm{MHz})$ spectrometers. ESI MS was recorded on a Thermo Finnigan LCQ with quaternary pump Rheos 4000 (Flux Instrument); Thermo Scientific, USA). EI mass spectra

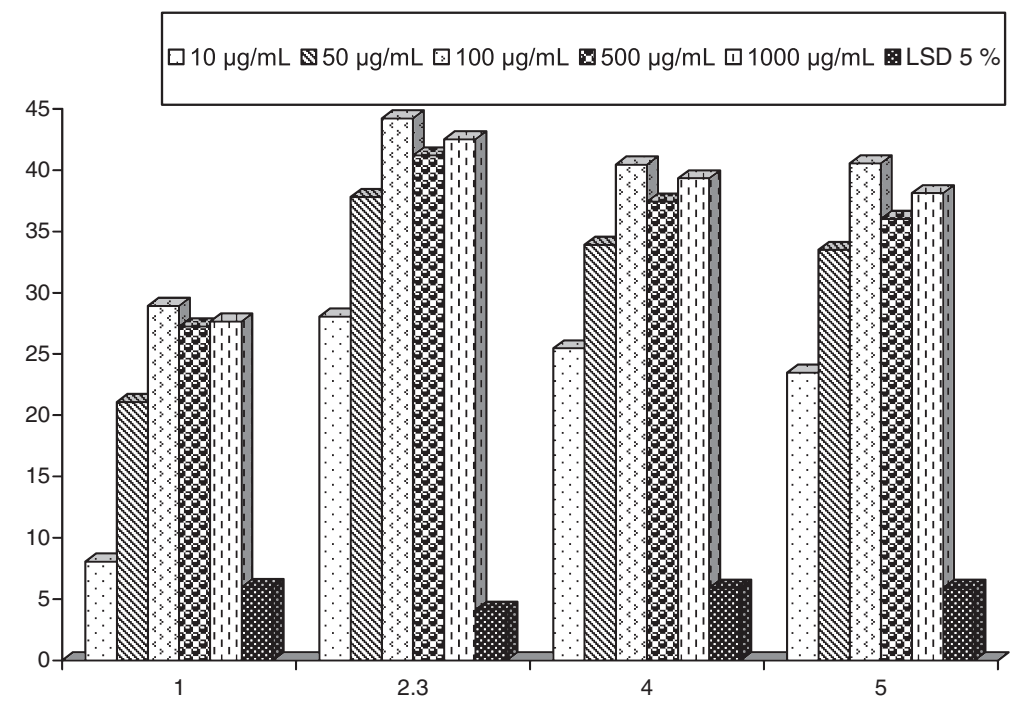

Figure $4 a$-Glucosidase inhibition percent of the four sponges extracts. 
Table 5 -galactosidase inhibition percent of four sponges extracts

\begin{tabular}{lllll}
\hline Concentrations & \multicolumn{3}{c}{ Extracts of the four sponges } \\
\cline { 2 - 5 } & SP1 & SP2 & SP3 & SP4 \\
\hline $10 \mu \mathrm{g} / \mathrm{mL}$ & $11.45 \pm 11.54^{\mathrm{b}}$ & $51.35 \pm 5.24^{\mathrm{b}}$ & $23.09 \pm 8.33^{\mathrm{b}}$ & $17.24 \pm 6.39^{\mathrm{c}}$ \\
$50 \mu \mathrm{g} / \mathrm{mL}$ & $31.58 \pm 22.03^{\mathrm{ab}}$ & $39.62 \pm 8.53^{\mathrm{bc}}$ & $34.78 \pm 11.03^{\mathrm{b}}$ & $35.35 \pm 9.72^{\mathrm{b}}$ \\
$100 \mu \mathrm{g} / \mathrm{mL}$ & $27.37 \pm 13.18^{\mathrm{ab}}$ & $34.49 \pm 11.82^{\mathrm{c}}$ & $36.49 \pm 8.35^{\mathrm{b}}$ & $33.53 \pm 11.38^{\mathrm{b}}$ \\
$500 \mu \mathrm{g} / \mathrm{mL}$ & $46.58 \pm 8.22^{\mathrm{a}}$ & $67.82 \pm 3.94^{\mathrm{a}}$ & $62.63 \pm 1.89^{\mathrm{a}}$ & $54.13 \pm 2.44^{\mathrm{a}}$ \\
$1000 \mu \mathrm{g} / \mathrm{mL}$ & $42.21 \pm 5.28^{\mathrm{a}}$ & $66.86 \pm 3.79^{\mathrm{a}}$ & $62.12 \pm 4.37^{\mathrm{a}}$ & $55.08 \pm 5.11^{\mathrm{a}}$ \\
LSD 5\% & 24.24 & 13.26 & 13.7 & 14.02 \\
\hline B-g & & &
\end{tabular}

$\beta$-galactosidase is expressed as\%; data are mean \pm SD of 3 replicates; statistical analysis is carried out using one way analysis of variance (ANOVA) using CoStat computer program; unshared superscript letters between treatments are significance values at $P<0.001$.

were recorded on a Finnigan MAT 95 spectrometer (70 eV); Thermo Scientific, USA. GC-MS was measured on a Trace GC-MS Thermo Finnigan chromatograph, ionization mode EI $(70 \mathrm{eV})$, instrument equipped with a capillary column CP-Sil $8 \mathrm{CB}$ for amines (length: $30 \mathrm{~m}$; inside diameter: $0.25 \mathrm{~mm}$; outside diameter: $0.35 \mathrm{~mm}$; film thickness: $0.25 \mu \mathrm{m}$ ); Thermo Scientific., USA. The analysis was carried out at a programmed temperature: initial temperature $40^{\circ} \mathrm{C}$ (kept for $1 \mathrm{~min}$ ), then increasing at a rate of $10^{\circ} \mathrm{C} / \mathrm{min}$ and final temperature $280^{\circ} \mathrm{C}$ (kept for $10 \mathrm{~min}$ ), injector temperature was $250^{\circ} \mathrm{C}$ and detector (mode of ionization: $\mathrm{EI}$ ) temperature at $250^{\circ} \mathrm{C}, \mathrm{He}$ was used as carrier gas at a flow rate of $1 \mathrm{~mL} / \mathrm{min}$, total run time $27 \mathrm{~min}$, injection volume $0.2 \mu \mathrm{L}$. Flash chromatography was carried out on silica gel (230-400 mesh). $R_{\mathrm{f}}$ values were measured on Polygram SIL G/UV ${ }_{254}$ TLC cards (Macherey-Nagel GmbH \& Co. Germany). Size exclusion chromatography was done on Sephadex LH20 (Lipophilic Sephadex, Amersham Biosciences Ltd. (purchased from Sigma-Aldrich Chemie, Steinheim, Germany). All chemicals served in the biological study were of analytical grade, which were purchased from Sigma, Merck and Aldrich. All kits were the products of Biosystems (Spain), Sigma Chemical Company (USA), Biodiagnostic (Egypt).

\section{Sponge materials, collection, and taxonomy}

Four varieties of sponges belonging to the genus Smenospongia (SP1, olieve, $0.75 \mathrm{~kg}$-wet), Callyspongia (SP2, faint brown, $0.42 \mathrm{~kg}$-wet), Niphates (SP3, faint greenish olieve, $0.15 \mathrm{~kg}$-wet), and Stylissa (SP4, orange, $0.16 \mathrm{~kg}$ wet) were collected from two sites at Hurghada-coasts, Red Sea, Egypt. The first site located north Hurghada at

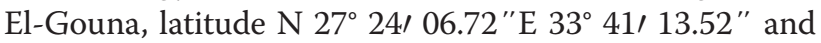
the second site is Shaa'b south Giffton island latitude N $27^{\circ} 10{ }^{\prime} 04.61^{\prime \prime} \mathrm{E} 33^{\circ}$ 57/ 04.87" (Figure 6). The sponge samples were collected at depth of $5-8 \mathrm{~m}$ in September of 2010 (Figure 7) and stored in a freezer until extraction. The four species were morphologically characterized by Mohamed A Ghani, and specimens of them were deposited at Red Sea Marine parks, P.O. Box 363-Hurgada, Red Sea, Egypt.

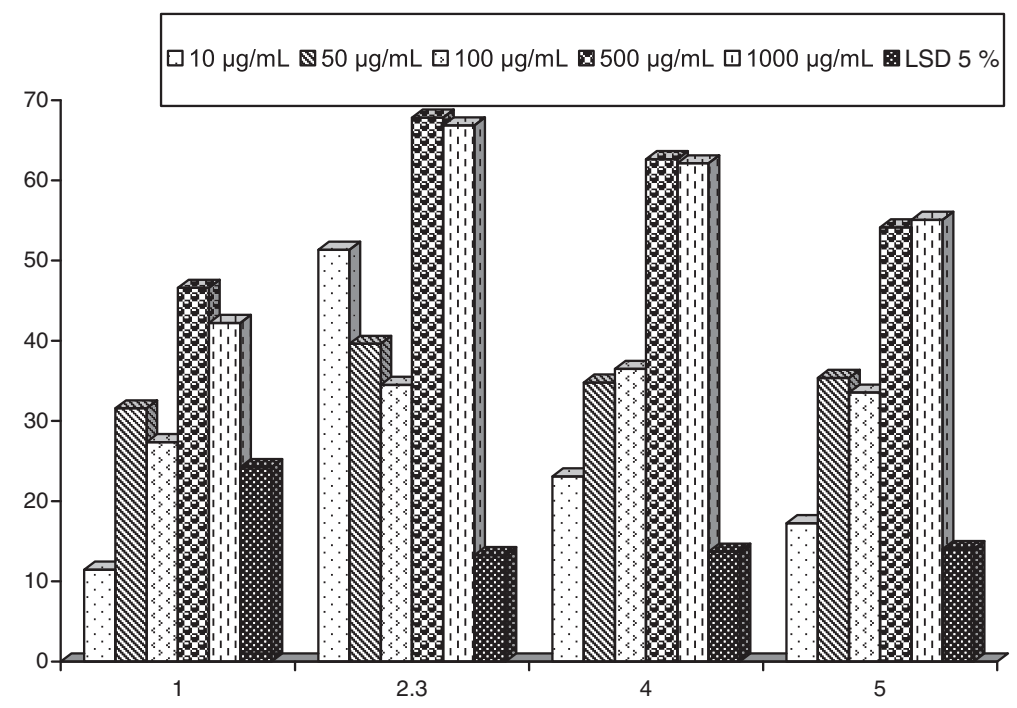

Figure $5 \beta$-Galactosidase inhibition percent of four sponges extracts. 


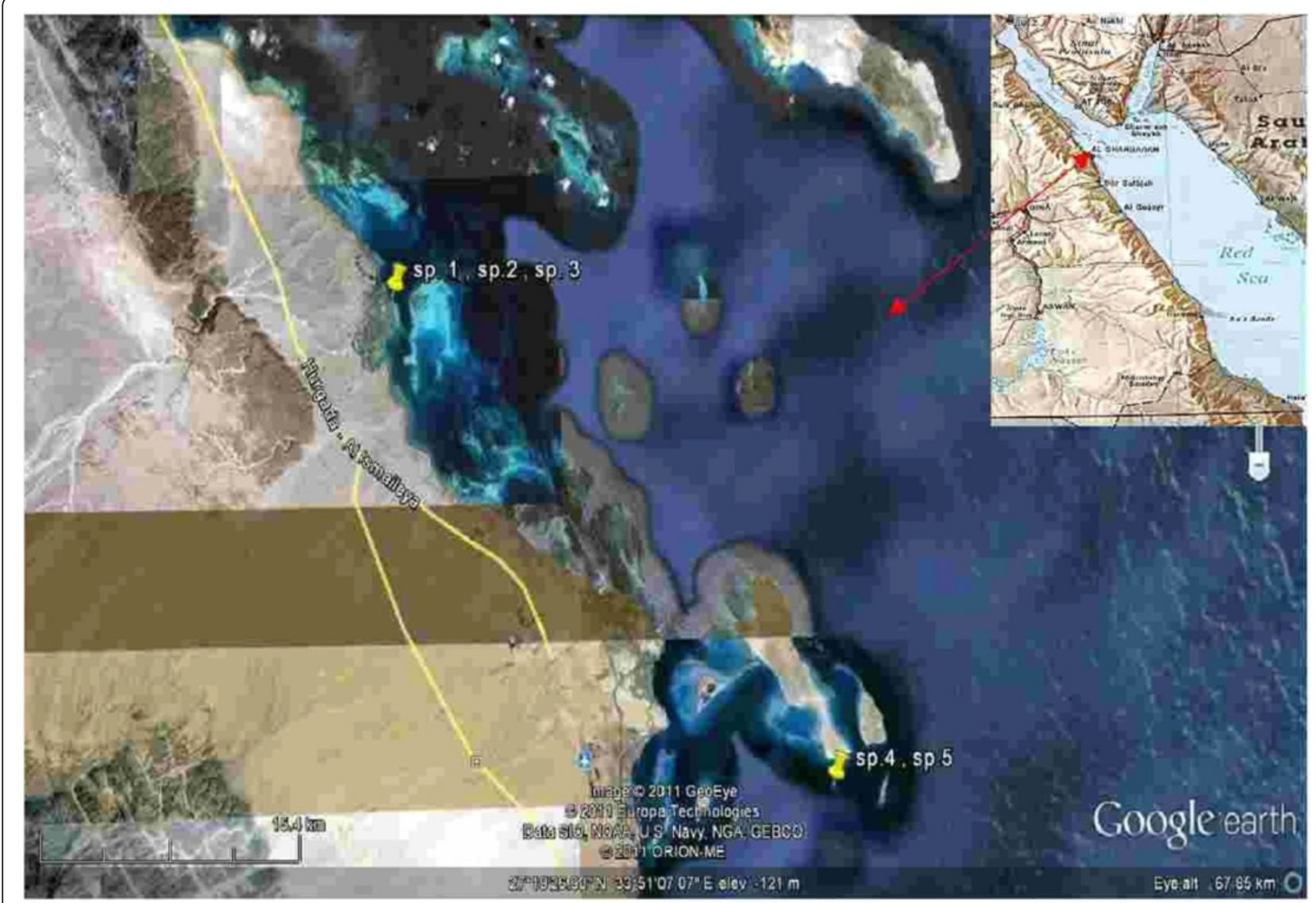

Figure 6 Red Sea satellite map show site locations of the collected sponges.

Taxonomically, the first species (SP1) was belonging to the genus Smenospongia, family Thorectidae. Morphologically, the SP1 is Massive with oscular mounds, displaying a bright to dark green coloration. The sponge exuded abundant mucus when handled, exhibiting blunt ends of primary protrude fibers on the surface $[34,35]$. The second sponge was belonging to the genus Callyspongia and family Callyspongiidae [36,37]. Morphologically, it showed bluish to pinkish tubes and sticky massive. Moreover, tissues of the sponge were clear away easily, leaving the clean skeleton. They inhabit as well in the coral reef habitat attached to corals or rocks. The third sponge was belonging to the genus Niphates and family Niphatidae. Morphologically, it is massive or encrusting, showing a bluish to purplish grayish cushions and repent branches [36,37]. Finally, the fourth sponge was belonging to the genus Stylissa and family Dictyonellidae [36,37]. Morphologically, it is bushy with orange color and tough consistency (Figures 7 and 8).

\section{Extraction and isolation}

The four sponges, Smenospongia (SP1), Callyspongia (SP2), Niphates (SP3) and Stylissa (SP4), were individually cut into small pieces and homogenized mechanically (Figure 1), treated with DCM-MeOH (2:1) and kept at approximately $5^{\circ} \mathrm{C}$ for 8 days. After filtration, the DCM layers were extracted and evaporated in vacuo to dryness affording $1.59,0.57,0.39$, and $0.64 \mathrm{~g}$ from sponges SP1, SP2, SP3, and SP4, respectively. In contrast with sponges SP1 and SP3, both sponges SP2 and SP4 were applied to a series of chromatographic purifications using silica gel, Sephadex, and PTLC affording no desired and inadequate compounds amounts.

\section{Working up and purification of smenospongia (SP1)}

The afforded greenish-brown crude extract of sponge 1 $(1.59 \mathrm{~g})$ was subjected to silica gel (column $3 \times 60 \mathrm{~cm}^{2}$ ) and eluted with a cyclohexane-hexane/DCM/MeOH gradient. Based on the TLC monitoring, visualized by UV and spraying with anisaldehyde/sulfuric acid, five fractions were obtained: FI $(0.1 \mathrm{~g})$, FII $(0.2 \mathrm{~g})$, FIII (0.3 g), FIV (0.3 g), and FV (0.4). The fast oil fraction I was applied to GC-MS analysis, displaying a base signal (RT: $25.04 \mathrm{~nm}, 100 \%$ ) of unknown component. Fraction II was likely subjected to GC-MS analysis showing four signals representing four components (RT: 13.79, 100\%), 

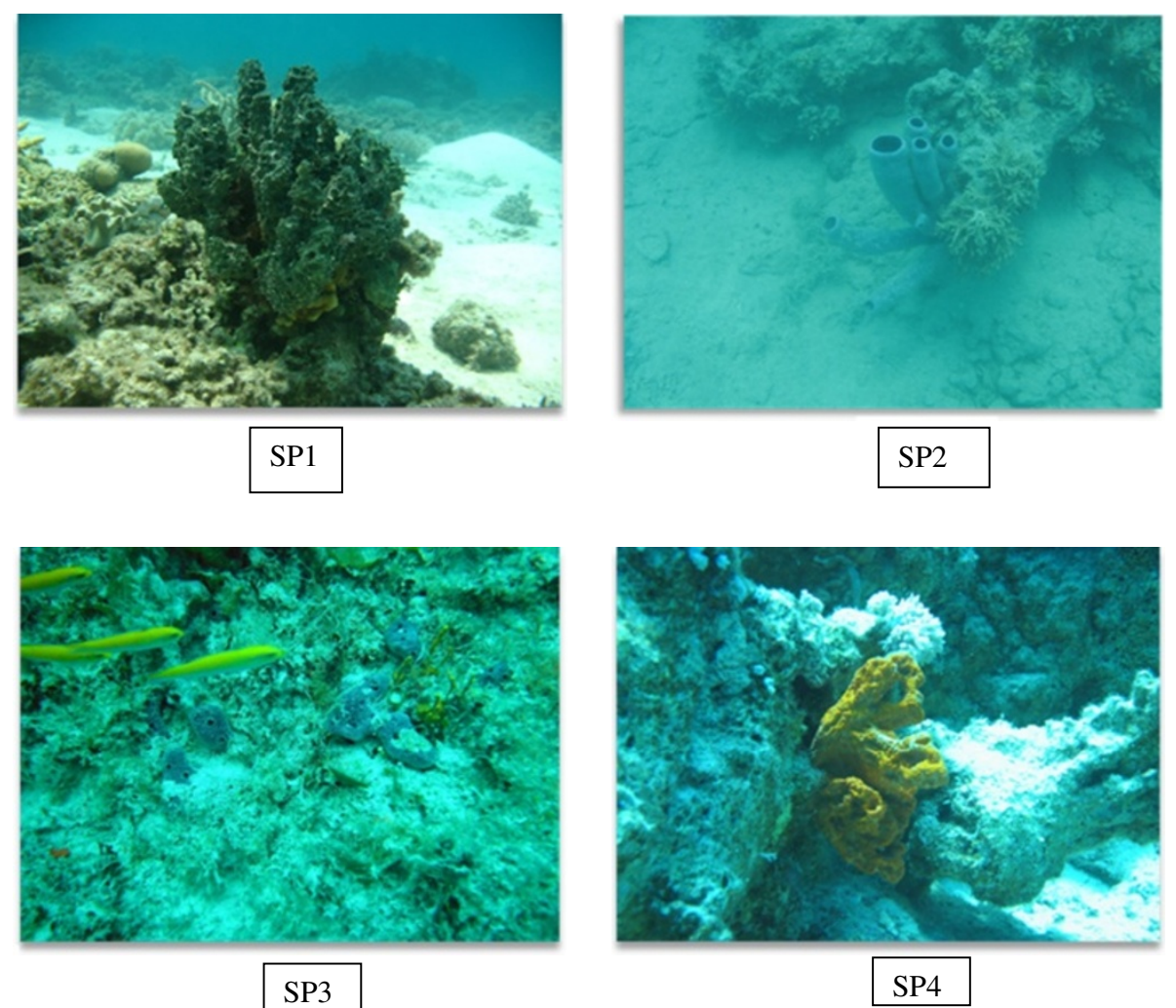

Figure 7 Photos of the collected four sponges (SP1, SP2, SP3, and SP4).

(14.84, 12\%), (19.03, 17\%), and (20.01, 78\%); the first two of them were of unknown structures, while the last two were assigned as di-isobutyl phthalate (1) and di- $n$-butyl phthalate (2). TLC monitoring of the remaining fractions (III, IV, and V) recognized their similarity, and they were combined therefore $(1.0 \mathrm{~g})$. Consequently, the combined fractions were then chromatographed on silica gel using
cyclohexane-DCM-MeOH gradient and after monitoring by TLC, six sub-fractions; PIa (80 mg), PIb (35 mg), PIc (70 mg), PId (95 mg), PIe (38 mg), and PIf (27 mg). An application of the sub-fractions to further purification using Sephadex LH-20 (DCM/MeOH, 60:40) was carried out. In accordance, sub-fractions PIa, PIc afforded a colorless semisolid of linoleic acid (3, $55 \mathrm{mg})$, while

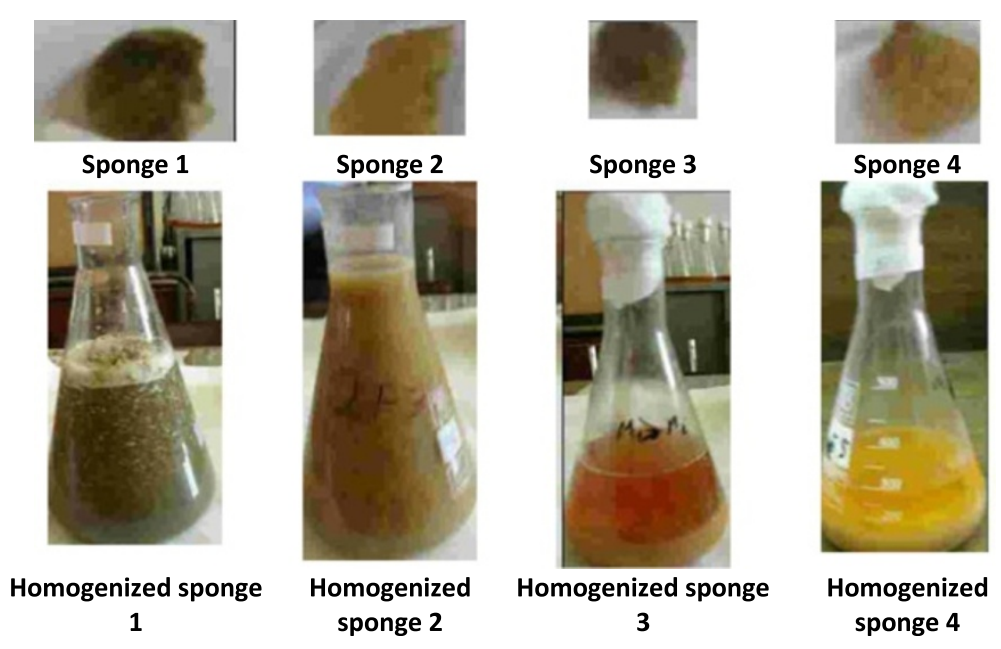

Figure 8 Macerated tissues of the collected four sponges (SP1, SP2, SP3, and SP4). 
purification of sub-fraction PIb afforded a colorless solid of $\beta$-sitosterol (4, $27 \mathrm{mg})$. Purification of sub-fraction PId afforded a colorless oil of an olefinic fatty acid (23 mg). Similarly, purification sub-fraction PIe yielded a colorless oil of an additional olefinic acid. Finally, an application of the sub-fraction PIf to Sephadex LH-20 (DCM/ $\mathrm{MeOH}, 60: 40)$ resulted in $\beta$-sitosterol (4, $3 \mathrm{mg})$ and cholesterol (5, $3 \mathrm{mg})$.

\section{Linoleic acid; (9Z,12Z)-9, 12-octadecanoic acid (3)}

Colorless oil (55 mg) was detected as non-polar UV absorbing band at $254 \mathrm{~nm}$ and stained to blue when sprayed by anisaldehyde/sulfuric acid and heated. $\mathbf{C}_{\mathbf{1 8}} \mathbf{H}_{32} \mathbf{O}_{2}(280) . \quad-\boldsymbol{R}_{\mathrm{f}}=0.90\left(\mathrm{CHCl}_{3} / \mathrm{MeOH}, 10 \%\right) .{ }^{\mathbf{1}} \mathbf{H}$ NMR $\left(\mathrm{CDCl}_{3}, 300 \mathrm{MHz}\right): \delta=8.98(\mathrm{~s}, \mathrm{br}, 1 \mathrm{H}, \mathrm{COOH})$, 5.43-5.28 (m, $4 \mathrm{H}, 9,10,12,13-\mathrm{CH}), 2.78\left(\mathrm{t},{ }^{3} J=6.0 \mathrm{~Hz}\right.$, $\left.2 \mathrm{H}, 11-\mathrm{CH}_{2}\right), 2.38\left(\mathrm{t},{ }^{3} \mathrm{~J}=7.2 \mathrm{~Hz}, 2 \mathrm{H}, 2-\mathrm{CH}_{2}\right), 2.08(\mathrm{~m}$, $\left.4 \mathrm{H}, 8,14-\mathrm{CH}_{2}\right), 1.63\left(\mathrm{~m}, 2 \mathrm{H}, 3-\mathrm{CH}_{2}\right), 1.42-1.23(\mathrm{~m}$, $\left.14 \mathrm{H}, 4,5,6,7,16,17-\mathrm{CH}_{2}\right), 0.85\left(\mathrm{~m}, 3 \mathrm{H}, 18-\mathrm{CH}_{3}\right) \cdot-{ }^{13} \mathrm{C} /$ APT NMR $\left(\mathrm{CDCl}_{3}, 50 \mathrm{MHz}\right): \delta=180.1\left(\mathrm{CO}, \mathrm{C}_{\mathrm{q}}\right), 130.1$ (CH-13), 129.9 (CH-9), 128.0 (CH-10), 127.8 (CH-12), $31.5\left(\mathrm{CH}_{2}-2\right), 29.6\left(\mathrm{CH}_{2}-16\right), 29.6\left(\mathrm{CH}_{2}-11\right), 29.5\left(\mathrm{CH}_{2}-\right.$ 14), $29.3\left(\mathrm{CH}_{2}-8\right), 29.1\left(\mathrm{CH}_{2}-7\right), 29.0\left(\mathrm{CH}_{2}-6\right), 29.0$ $\left(\mathrm{CH}_{2}-5\right), 27.1\left(\mathrm{CH}_{2}-4\right), 25.6\left(\mathrm{CH}_{2}-3\right), 24.7\left(\mathrm{CH}_{2}-15\right), 22.5$ $\left(\mathrm{CH}_{2}-17\right) 14.0\left(\mathrm{CH}_{2}-18\right)$. -EI MS $(70 \mathrm{eV}): \mathrm{m} / z(\%)=280$ (80), 264 (28), 137 (10), 124 (15), 110 (28), 95 (60), 81 (84), 67 (100), 55 (92), 41 (92).

\section{$\beta$-sitosterol (4)}

Colorless solid, UV non-absorbing, turned blue on spraying with anisaldehyde/sulfuric. $-\mathbf{C}_{29} \mathbf{H}_{50} \mathrm{O}$ (414). $\boldsymbol{R}_{\mathbf{f}}=0.51\left(\mathrm{CH}_{2} \mathrm{Cl}_{2} / \mathrm{CH}_{3} \mathrm{OH}\right.$ 9: 0.5). ${ }^{\mathbf{1}} \mathbf{H}$ NMR $\left(\mathrm{CDCl}_{3}\right.$, $300 \mathrm{MHz}): \boldsymbol{\delta}=5.36(\mathrm{~d}, J=4.7 \mathrm{~Hz}, 1 \mathrm{H}, \mathrm{H}-6), 3.53(\mathrm{~m}$, $1 \mathrm{H}, \mathrm{H}-3$ ), 2.36-2.21 (m, $4 \mathrm{H}, \mathrm{H}_{2}-1, \mathrm{H}_{2}-4$ ), 2.01-1.93 (m, $\left.2 \mathrm{H}, \mathrm{H}_{2}-6\right)$, $1.85-1.75(\mathrm{~m}, 4 \mathrm{H}), 1.58-1.43(\mathrm{~m}, 5 \mathrm{H})$, 1.21-1.03 (m, $14 \mathrm{H}), 0.99$ (s, $\left.3 \mathrm{H}, \mathrm{CH}_{3}-19\right), 0.94$ (d, $3 \mathrm{H}$, $\left.J=6.1 \mathrm{~Hz}, \mathrm{CH}_{3}-21\right), 0.86\left(\mathrm{~d}, 3 \mathrm{H}, J=6.2 \mathrm{~Hz}, \mathrm{CH}_{3}-26\right)$, 0.84 (d, $\left.3 \mathrm{H}, J=6.2 \mathrm{~Hz}, \mathrm{CH}_{3}-27\right), 0.79$ (t, $3 \mathrm{H}, J=6.7$, $\mathrm{CH}_{3}$-29), 0.67 (s, $\left.3 \mathrm{H}, \mathrm{CH}_{3}-18\right)$. -EI-MS (70 eV): $\mathrm{m} / z$ $(\%)=414\left([\mathrm{M}]^{+}, 100\right), 396\left(\left[\mathrm{M}-\mathrm{H}_{2} \mathrm{O}\right]^{+}, 37\right), 381(21), 329$ (34), 303 (41), 283 (16), 259 (10), 241 (22), 227 (9), 206 (11), 189 (18), 173 (22), 151 (13), 135 (25), 123 (21), 109 (18), 83 (13), 43 (15).

\section{Cholesterol (5)}

Colorless solid, UV non-absorbing, turned blue on spraying with anisaldehyde/sulfuric. $-\mathbf{C}_{27} \mathbf{H}_{46} \mathbf{O}$ (386). $-\boldsymbol{R}_{\mathbf{f}}=$ 0.47 $\left(\mathrm{CH}_{2} \mathrm{Cl}_{2} / \mathrm{CH}_{3} \mathrm{OH} \quad 9: 0.5\right) . \quad-{ }^{1} \mathbf{H} \quad$ NMR $\quad\left(\mathrm{CDCl}_{3}\right.$, $300 \mathrm{MHz}): \delta=5.37(\mathrm{~d}, J=4.7 \mathrm{~Hz}, 1 \mathrm{H}, \mathrm{H}-6), 3.51(\mathrm{~m}, 1 \mathrm{H}$, $\mathrm{H}-3$ ), 2.35-2.19 (m, $\left.4 \mathrm{H}, \mathrm{H}_{2}-1, \mathrm{H}_{2}-4\right), 2.02-1.94(\mathrm{~m}, 2 \mathrm{H}$, $\left.\mathrm{H}_{2}-6\right)$, 1.85-1.75 (m, 4 H), 1.58-1.43 (m, $\left.6 \mathrm{H}\right), 1.18-1.02$ (m, $12 \mathrm{H}), 0.99$ (s, $\left.3 \mathrm{H}, \mathrm{CH}_{3}-19\right), 0.94(\mathrm{~d}, 3 \mathrm{H}, J=6.1 \mathrm{~Hz}$, $\left.\mathrm{CH}_{3}-21\right), 0.86$ (d, $\left.3 \mathrm{H}, J=6.2 \mathrm{~Hz}, \mathrm{CH}_{3}-26\right), 0.84$ (d, $3 \mathrm{H}, J$ $\left.=6.2 \mathrm{~Hz}, \mathrm{CH}_{3}-27\right), 0.67$ (s, $\left.3 \mathrm{H}, \mathrm{CH}_{3}-18\right) .-{ }^{13} \mathrm{C}$ NMR
$\left(\mathrm{CDCl}_{3}, 75 \mathrm{MHz}\right): \delta=42.7\left(\mathrm{C}_{\mathrm{q}}, \mathrm{C}-13\right), 36.7(\mathrm{CH}, \mathrm{C}-1)$, $140.6\left(\mathrm{C}_{\mathrm{q}}, \mathrm{C}-5\right), 56.4(\mathrm{CH}, \mathrm{C}-14), 50.2(\mathrm{CH}, \mathrm{C}-9), 31.8$ $(\mathrm{CH}, \mathrm{C}-8), 56.3(\mathrm{CH}, \mathrm{C}-17) 121.8(\mathrm{CH}, \mathrm{C}-6), 40.0\left(\mathrm{CH}_{2}\right.$, C-24), $32.0\left(\mathrm{CH}_{2}, \mathrm{C}-16\right), 21.0\left(\mathrm{CH}_{2}, \mathrm{C}-11\right), 24.3\left(\mathrm{CH}_{2}, \mathrm{C}-\right.$ 15), $37.3\left(\mathrm{C}_{\mathrm{q}}, \mathrm{C}-10\right), 28.2(\mathrm{CH}, \mathrm{C}-25), 42.3\left(\mathrm{C}_{\mathrm{q}}, \mathrm{C}-4\right), 35.9$ $\left(\mathrm{CH}_{2}, \mathrm{C}-12\right), 12.1\left(\mathrm{CH}_{3}, \mathrm{C}-18\right), 31.7\left(\mathrm{CH}_{2}, \mathrm{C}-7\right), 31.2$ $\left(\mathrm{CH}_{2}, \mathrm{C}-2\right), 71.5(\mathrm{CH}, \mathrm{C}-3), 19.4\left(\mathrm{CH}_{3}, \mathrm{C}-19\right), 24.0\left(\mathrm{CH}_{2}\right.$, C-23), $36.3\left(\mathrm{CH}_{2}, \mathrm{C}-22\right), 18.8\left(\mathrm{CH}_{3}, \mathrm{C}-21\right), 35.8(\mathrm{CH}, \mathrm{C}-$ 20), $22.6\left(\mathrm{CH}_{3}, 26\right), 22.6\left(\mathrm{CH}_{3}, 27\right)$. -EI-MS $(70 \mathrm{eV}): \mathrm{m} / z$ $(\%)=386\left([\mathrm{M}]^{+}, 100\right), 368\left(\left[\mathrm{M}-\mathrm{H}_{2} \mathrm{O}\right]^{+}, 36\right), 353(20), 301$ (32), 275 (40), 255 (18), 231 (12), 213 (21), 199 (8), 178 (12), 161 (16), 145 (21), 133 (12), 107 (24), 95 (20), 81 (17), 55 (14), 43 (16).

\section{Working up and purification of callyspongia (SP3)}

The afforded reddish-brown crude extract of sponge 3 $(0.39 \mathrm{~g})$ was subjected to silica gel column $(2 \times 50 \mathrm{~cm})$ and eluted with a cyclohexane-hexane/DCM/MeOH gradient. According to TLC monitoring, visualized by UV and spraying with anisaldehyde/sulfuric acid, three fractions were obtained: FIa (140 mg), FIb (70 mg), and FIc (60 mg). Purification of FIa using Sephadex LH-20 (DCM/MeOH, 60:40) afforded a colorless oil of phthylester (6, $80 \mathrm{mg})$. Purification of FIb by Sephadex LH-20 $(\mathrm{DCM} / \mathrm{MeOH}, 60: 40)$ resulted in a colorless oil of triglyceride fatty acid ester mixture (7, $35 \mathrm{mg})$. An application of fraction FIc to purification with Sephadex LH-20 (DCM/MeOH, 60:40) afforded a colorless solid of cholesterol (5, $28 \mathrm{mg})$.

\section{Di-(2-ethylhexyl)phthalate(DEHP)(6)}

UV-absorbing $(254 \mathrm{~nm})$ turned intensive violet on spraying with anisaldehyde/sulfuric acid after heating, and changed latter as blue. $-\mathbf{C}_{\mathbf{2 4}} \mathbf{H}_{\mathbf{3 8}} \mathbf{O}_{\mathbf{4}} \quad$ (390). $\quad-\boldsymbol{R}_{\mathbf{f}}=0.90$; $\mathrm{CHCl}_{3} .{ }^{1}{ }^{1} \mathbf{H}$ NMR $\left(\mathrm{CDCl}_{3}, 300 \mathrm{MHz}\right): \delta=7.70(\mathrm{~m}, 2 \mathrm{H})$, $7.50(\mathrm{~m}, 2 \mathrm{H}), 4.25\left(\mathrm{~d},{ }^{3} \mathrm{~J}=5 \mathrm{~Hz}, 2 \mathrm{H}\right), 1.80-1.20$ (br m, $18 \mathrm{H}), 1.00-0.75$ (br m, $12 \mathrm{H}) . \quad-{ }^{\mathbf{1 3}} \mathbf{C ~ N M R}\left(\mathrm{CDCl}_{3}\right.$, $75 \mathrm{MHz}): \delta=167.7\left(\mathrm{C}_{\mathrm{q}}-1 /, 1^{\prime \prime}\right), 132.4\left(\mathrm{C}_{\mathrm{q}}-1,2\right), 130.9(\mathrm{CH}-$ 3,6), 128.8 (CH-4,5), $68.1\left(\mathrm{CH}_{2}-2 \prime, 2^{\prime \prime}\right), 38.7$ (CH-3/,3"), $30.3\left(\mathrm{CH}_{2}-4 /, 4^{\prime \prime}\right), 28.9\left(\mathrm{CH}_{2}-5 /, 5^{\prime \prime}\right), 22.9\left(\mathrm{CH}_{2}-6 /, 6^{\prime \prime}\right), 14.0$ $\left(\mathrm{CH}_{3}-7 /, 7^{\prime \prime}\right), 23.7\left(\mathrm{CH}_{2}-8 /, 8^{\prime \prime}\right), 10.9\left(\mathrm{CH}_{3}-9 /, 9^{\prime \prime}\right)$. -EI-MS $(70 \mathrm{eV}): m / z: 390$ (3), 279 (20), 149 (64). -CI-MS $\left(\mathrm{NH}_{3}\right)$ : $798\left(\left[2 \mathrm{M}+\mathrm{NH}_{4}\right]^{+}, 62 \%\right), 408\left(\left[\mathrm{M}+\mathrm{NH}_{4}\right]^{+}, 100\right), 391$ $\left([\mathrm{M}+\mathrm{H}]^{+}, 65\right)$.

\section{Triglyceride fatty acids mixture (7)}

Colorless oil, turned violet by anisaldehyde/sulfuric acid; $-\boldsymbol{R}_{\mathbf{f}}=0.78\left(\mathrm{CH}_{2} \mathrm{Cl}_{2}\right) .{ }^{\mathbf{1}} \mathbf{H} \mathbf{N M R}\left(300 \mathrm{MHz}, \mathrm{CDCl}_{3}\right): \delta=$ $5.37(\mathrm{~m}, 2 \mathrm{H}), 5.34(\mathrm{~m} 2 \mathrm{H}), 5.27(\mathrm{~m}, 1 \mathrm{H}), 4.30(\mathrm{dd}, 2 \mathrm{H}$, $J=11.9,4.3 \mathrm{~Hz}), 4.14(\mathrm{dd}, 2 \mathrm{H}, J=11.9,6.0 \mathrm{~Hz}), 2.81(\mathrm{~m}$, $2 \mathrm{H}), 2.31$ (m, $2 \mathrm{H}), 2.02$ (m, $4 \mathrm{H}), 1.61$ (m, $2 \mathrm{H}), 1.40$ $1.20(\mathrm{~m}, 22 \mathrm{H})$, and $0.88(\mathrm{t}, 9 \mathrm{H}, J=6.9 \mathrm{~Hz}) .-{ }^{13} \mathrm{C} \mathrm{NMR}$ $\left(75 \mathrm{MHz}, \mathrm{CDCl}_{3}\right): \delta=172.9\left(2 \mathrm{C}_{\mathrm{q}}, \mathrm{CO}\right), 172.5\left(\mathrm{C}_{\mathrm{q}}, \mathrm{CO}\right)$, $129.5(2 \mathrm{CH}), 129.1(2 \mathrm{CH}), 132-127$ (further $\mathrm{mCH}), 68.8$ 
$(\mathrm{CH}), 62.5\left(2 \mathrm{CH}_{2}\right), 34.0\left(\mathrm{CH}_{2}\right), 31.9\left(\mathrm{CH}_{2}\right), 29.8\left(\mathrm{CH}_{2}\right)$, $29.7\left(\mathrm{CH}_{2}\right) 29.6\left(\mathrm{CH}_{2}\right) 29.5\left(\mathrm{CH}_{2}\right) 29.4\left(\mathrm{CH}_{2}\right) 29.3\left(\mathrm{CH}_{2}\right)$ $29.2\left(\mathrm{CH}_{2}\right) 29.0\left(\mathrm{CH}_{2}\right) 29.1\left(\mathrm{CH}_{2}\right), 29.0\left(\mathrm{CH}_{2}\right), 27.2\left(\mathrm{CH}_{2}\right)$, $25.6\left(\mathrm{CH}_{2}\right), 24.9\left(\mathrm{CH}_{2}\right), 22.7\left(\mathrm{CH}_{2}\right)$ and $14.1\left(\mathrm{CH}_{3}\right)$.

\section{In vitro antioxidant study \\ Purified enzymes}

Carbohydrate metabolizing enzymes; $\alpha$-amylase, $\alpha$-glucosidase, and $\beta$-galactosidase (EC3.2.1.1, EC3.2.1.20, and EC3.2.1.23, respectively) were obtained from Sigma Chemical Company (USA).

\section{The antioxidant scavenging activity}

The activity of serial concentrations of different sponge extracts $(10: 1000 \mu \mathrm{g} / \mathrm{mL})$ on DPPH-free radical will performed according to the method of McCue et al. [36] and Katsube et al. [37]. The decrease in optical density of $\mathrm{DPPH}^{-}$is calculated compared with a control substance as follows:

\%Inhibition $=A_{\text {control }}-A_{\text {sample }} \times 100$

\section{Determination of NO-free radical scavenging activity}

NO-scavenging activity of extracts was determined according to the method of Sreejayan and Rao [16].

\section{Determination of a-amylase}

$\alpha$-Amylase was determined according to the method of Bernfeld [38].

\section{Determination of $\beta$-galactosidase activity}

$\beta$-galactosidase was measured by the method of Sánchez and Hardisson [39].

\section{Estimation of a-glucosidase activity}

$\alpha$-glucosidase activity was determined according to the method of Kapustka et al. [40] and Kim et al. [32].

\section{Conclusions}

In conclusion, this study was performed to investigate the effects of the extracts of four marine sponges on some biochemical parameters including antioxidant and three different carbohydrate hydrolyzing enzymes ( $\alpha$-amylase, $\beta$ galactosidase, and $\alpha$-glucosidase). These sponges were collected from Red Sea at Egyptian coasts, which were taxonomically belonged to the genus of Smenospongia (SP1), Callyspongia (SP2), Niphates (SP3), and Stylissa (SP4). The results demonstrated that different extracts exhibited inhibitory effects on oxidative stress indices and carbohydrate hydrolyzing enzymes in linear relationships to some extent with concentration of inhibitors (dose dependant). The extracts of sponges (3, 1, and 2) showed, respectively, potent-reducing power. Chemical characterizations of sponges SP1 and SP3 were discussed, at where di-isobutyl phthalate (1), di- $n$-butyl phthalate (2), linoleic acid (3), $\beta$-sitosterol (4), and cholesterol (5) were obtained from sponge SP1; while sponge SP3 produced bis-[2-ethyl]hexyl-phthylester (6) and triglyceride fatty acid ester (7).

\section{Competing interests}

The authors declare that they have no competing interests.

\section{Authors' contributions}

MS is the principle investigator of the research work, who is responsible for points of research in the manuscript. Additionally, he is the responsible investigator for the structural elucidation of the isolated bioactive compounds, in additions to control the whole manuscript research points. $\mathrm{HIA}-\mathrm{A}$ and $\mathrm{AZH}$ are the chemists who mainly made the main work of extraction and isolation of the bioactive constituents obtained from the sponges under study. HFA is the main investigator who studied the whole biological part of the obtained sponges extracts of the research work under study. MAG is the main investigator who collected the sponges under study together with their full taxonomical study. All authors read and approved the final manuscript.

\section{Acknowledgments}

The authors are deeply thankful to Prof. H. Laatsch for his Lab facilities and unlimited support. This research work has been financed during German Egyptian Scientific Projects (GESP) No. 7.

\section{Author details}

${ }^{1}$ Chemistry of Natural Compounds Department, Division of Pharmaceutical Industries, National Research Centre, Dokki, Giza 12622, Egypt. ${ }^{2}$ Institute of Organic and Biomolecular Chemistry, University of Göttingen, Tammannstraße 2, Göttingen D-37077, Germany. ${ }^{3}$ Department of Therapeutic Chemistry, National Research Centre, Dokki, Giza 12622, Egypt ${ }^{4}$ Red Sea Marine Parks, P.O. Box 363, Hurghada, Red Sea, Egypt.

Received: 17 January 2012 Accepted: 5 April 2012

Published: 16 August 2012

References

1. Bergmann W, Feeney RJ: The isolation of a new thymine pentoside from sponges. J Am Chem Soc 1950, 72:2809-2810.

2. Bergmann W, Feeney RJ: Contributions to the study of marine products. XXXII. The nucleosides of sponges. I. J Org Chem 1951, 16:981-987.

3. Proksch P, Edrada R, Ebel R: Drugs from the seas-current status and microbiological implications. Appl Microbiol Biotechnol 2002, 59:125-134.

4. Faulkner DJ: Marine natural products. Nat Prod Rep 2002, 19:1-48.

5. Blunt JW, Copp BR, Hu W-P, Munro MHG, Northcote PT, Prinsep MR: Marine natural products. Nat Prod Rep 2009, 26:170-244.

6. Gordaliza M: Review: cytotoxic terpene quinones from marine sponges. Mar Drugs 2010, 8:2849-2870.

7. Zhu YM, Shen JK, Wang HK, Cosentino LM, Lee KH: Synthesis and anti-HIV activity of oleanolic acid derivatives. Bioorg Med Chem Lett 2001, 11:3115-3118.

8. Hsu YL, Kuo PL, Lin CC: Proliferative inhibition, cell-cycle dysregulation and induction of apoptosis by ursolic acid in human non-small cell lung cancer A549 cell. Life Sci 2004, 75:2303-2316.

9. Yogeeswari P, Sriram D: Betulinic acid and its derivatives: a review on their biological properties. Curr Med Chem 2005, 12:657-666.

10. Gulcin I, Buyukokuroglu ME, Oktay M, Kufrevioglu Ol: On the in vitro antioxidative properties of melatonin. J Pineal Res 2002, 33:167-171.

11. Wang H, Cao G, Prior RL: Total antioxidant capacity of fruits. J Agr Food Chem 1996, 44:701-705.

12. Dudhgaonkar S, Thyagarajan A, Sliva D: Suppression of the inflammatory response by triterpenes isolated from the mushroom Ganoderma lucidum. Int Immunopharmacol 2009, 9:1272-1280.

13. Berrue F, Thomas OP, Laville R, Prado S, Golebiowski J, Fernandezc R, Amadea P: The marine sponge Plakortis zyggompha: a source of original bioactive polyketides. Tetrahedron 2007, 63:2328-2334.

14. Teeyapant R, Woerdenbag HJ, Kreis P, Hacher J, Wray V: Antibiotic and cytotoxic activity of K. Cyclostelletamines A-F; pyridine alkaloids which 
inhibit brominated compound from marine sponge Verongia aerobinding of quinuclidinyl benzilate (QNB) to muscarinic acephoba. Z Naturforsch 1993, 48C:939-945.

15. Bartolotta SA, Scuteri MA, Hick AS, Palermo J, Rodriguez BMF, Hajdu E, Mothes B, Lerner C, Campos M, Carballo MA: Evaluation of genotoxic biomarkers in extracts of marine sponges from Argentinean South Sea. J Exp Mar Biol Ecol 2009, 369:144-147.

16. Sreejayan N, Rao MNA: Nitric oxide scavenging by curcuminoids. J Pharm Pharmacol 1997, 49:105-107.

17. Khotimchenko S: V: fatty acids of brown algae from the Russian far east. Phytochemistry 1998, 49:2363-2369.

18. Viqar Uddin A, Shaheen B: Isolation of $\beta$-sitosterol and ursolic acid from Morinda Citrifolia Linn. J Chem Soc Pak 1980, 2:71.

19. Md AM, Tareq SM, Apu AS, Basak D, Islam MS: Isolation and identification of compounds from the leaf extract of Dillenia indica Linn. Bangladesh Pharm J 2010, 13:49-53.

20. Laatsch H: AntiBase: a data base for rapid dereplication and structure determination of microbial natural products. Weinheim, Germany: Wiley-VCH; 2010. http://wwwuser.gwdg. de/ ucoc/laatsch/AntiBase.htm.

21. Volkman JK, Farmer CL, Barrett SM, Sikes EL: Unusual dihydroxysterols as chemotaxonomic markers for microalgae from the order Pavlovales (Haptophyceae). J Phycol 1997, 33:1016-1023.

22. Subramanian A, Joshi BS, Roy AD, Gupta RRV, Dang RS: NMR spectroscopic identification of cholesterol esters, plasmalogen and phenolic glycolipids as fingerprint markers of human intracranial tuberculomas. NMR Biomed 2008, 21:272-288.

23. Ahmad VU, Memon AH, Ali MS, Perveen S, Shameel M: Somalenone, a C26 sterol from the marine red alga Melanothamnus somalensis. Phytochemistry 1996, 42:1141-1143.

24. Sherif EAB, Shaaban M, Elkholy YM, Helal MH, Hamza AS, Masoud MS, El Safty MM: Chemical composition and biological activity of ripe pumpkin fruits (Cucurbita pepo L.) cultivated in Egyptian habitats. Nat Prod Res 2011, 25:1524-1539.

25. Sani UM, Pateh UU: Isolation of 1,2-benzenedicarboxylic acid bis(2-ethylhexyl) ester from methanol extract of the variety minor seeds of Ricinus communis Linn. (Euphorbiaceae). Nig J Pharm Sci 2009, 8:107-114.

26. Sato $\mathrm{S}$, Kuramoto $\mathrm{M}$, Ono N: Ircinamine B, bioactive alkaloid from marine sponge Dactylia sp. Tetrahedron Lett 2006, 47:7871-7873.

27. Brinker M, Ma J, Lipsky PE, Raskin I: Medical chemistry and pharmacology of genus Tripterygium (Celastraceae). Phytochemistry 2007, 68:732-766.

28. Tasi PJ, Tsai TH, Yu CH, Ho SC: Evaluation of no-suppressing activity of several Mediterranean culinary spices. Food Chem Toxicol 2007, 45:440-447.

29. Diouf PN, Stevanovic T, Boutin Y: The effect of extraction process on polyphenol content, triterpene composition and bioactivity of yellow birch (Betula alleghaniensis Britton) extracts. Ind Crops Prod 2009, 30:297-303

30. Rohn S, Rawel HM, Kroll J: Inhibitory effects of plant phenols on the activity of selected enzymes. J Agric Food Chem 2002, 50:3566-3571.

31. Rhabasa-Lhoret R, Chiasson JL: Alpha glucosidase inhibitors. In International textbook of diabetes mellitus, 3rd edn, Volume 1. Edited by Defronzo RA, Ferrannini E, Keen H, Zimmet P. UK: John Wiley \& Sons Ltd; 2004:901-914.

32. Kim YM, Jeong YK, Wang MH, Lee WY, Rhee HI: Inhibitory effect of Pine erglycemia. Nutrition 2005, 21:756-761.

33. Manosroi J, Dhumtanom P, Manosroi A: Anti-proliferative activity of essential oil extracted from Thai medicinal plants on KB and P388 cell lines. Cancer Lett 2006, 235:114-120.

34. Pulitzer-Finali G: A collection of west Indian Demospongiae (Porifera). In In appendix, a list of the Demospongiae hitherto recorded from the West Indies. 86th edition. Gincoma Doria: Annali de1 musco civico di storia naturale; 1986:65-216.

35. John N, Hooper A, Van Soest RWM: Systema porifera. A guide to the classification of sponges: Kluwer Academic/Plenum Publishers, New York; 2002.

36. McCue P, Horii A, Shetty K: Solid-state bioconversion of phenolic antioxidants from defatted soybean powders by Rhizopus oligosporus: role of carbohydrate-cleaving enzymes. J Food Biochem 2003, 27:501-514.

37. Katsube T, Tabata H, Ohta Y, Yamasaki Y, Anuurad E, Shiwaku K, Yamane Y. Screening for the antioxidant activity in edible plant products: comparison of low-density lipoprotein oxidation assay, DPPH radical scavenging assay, and Folin-Ciocalteu assay. J Agric Food Chem 2004, 52:2391-2396

38. Bernfeld P: Amylases, alpha and beta. Meth Enzymol 1955, 1:149-158.

39. Sánchez J, Hardisson C: Glucose inhibition of galactose-induced synthesis of $\beta$-galactosidase in Streptomyces violaceus. Arch Crobial 1979, 125:111-114.

40. Kapustka LA, Annala AE, Swanson WC: The peroxidase-glucose oxidase system: a new method to determine glucose liberated by carbohydrate degradino soil enzymes. Plant Soil 1981, 63:487-490.

doi:10.1186/2191-2858-2-30

Cite this article as: Shaaban et al:: Chemical characterization, antioxidant and inhibitory effects of some marine sponges against carbohydrate metabolizing enzymes. Organic and Medicinal Chemistry Letters 2012 2:30.

\section{Submit your manuscript to a SpringerOpen ${ }^{\odot}$ journal and benefit from:}

- Convenient online submission

- Rigorous peer review

- Immediate publication on acceptance

- Open access: articles freely available online

- High visibility within the field

- Retaining the copyright to your article

Submit your next manuscript at $>$ springeropen.com 